\title{
Suitability of Bambara Groundnut (Vigna Subterranean) as An Alternative to Peanut Matrix for Development and Production of Low-Fat Food Spread
}

\author{
Yusuf Amina Osizemeyele, Odion-Owase, Emmanuel And Suleiman Mohammed \\ Department of Food Technology, Auchi Polytechnic Auchi
}

\begin{abstract}
Bambara groundnut $(\mathrm{BGN})$ is an underutilized crop grown in Nigeria. Few types are consumed in rural household which they use traditional methods to cultivate and process into traditional food products. Knowledge of the preparation of food spread would add value to utilization and processing of Bambara groundnut. In this study, low fat spread was prepared from roaster, blanched, dehulled and dried back to moisture of $12 \%$ Bambara groundnut flour and pea nut spread used as control. Seven (7) samples were prepared: in the ratio 90: 10, 80:20, $70: 30,60: 40,50: 50,100: 0,100: 0$, peanuts which serve as control, (XY1, XY2, XY3, XY4, XY5, XY6 and $\mathrm{XY7}$ ), The proximate, amino acids composition and anti-nutritional factors composition of low-fat food spread were investigated. The proximate composition increased with the level of substitution with peanut. Protein content of low-fat food spread (18.77-25.34) Ash and fibers in all the low-fat food spread samples produced, were different from each other. Moisture content range (7.30-37.64) sample XY7 had the highest. Carbohydrate range (21.71-58.71) sample XY6 with the highest and XY7 the lowest. Lipids range (5.70-32.09) XY7 with the highest values. Amino acids content of the low-fat food spread samples produced were comparable to FAO/WHO (2007) recommended requirements. Anti-nutritional factors composition in all the formulated samples were: Oxalate (0.95-9,04), tannins) $5.20-39.81)$, phytate (0.00-45.36) $\mathrm{mg} / \mathrm{g}$ and trypsin inhibitor, $(0.51$ 17.24) $\mathrm{TIU} / \mathrm{mL}$ and were within tolerable limits. The research has established that acceptable food spread could be potentially produced from Bambara groundnuts.
\end{abstract}

Keywords: Bambara groundnut, Suitability, Alternative, low-fat food spread, Amino acids.

DOI: $10.7176 / \mathrm{JNSR} / 12-20-03$

Publication date:October $31^{\text {st }} 2021$

\section{Introduction}

Bambara groundnut is a legume indigenous to Africa grown mainly for its edible seed (Bamshaiye O. Adegbola, Bamshaiye 2011). It has origin in the Sahelian region of West Africa. The third most important legume after groundnut (Arachis hypogea) and cow pea (Vigna unguculata)

It is indigenous, draught tolerant and underutilized and widely cultivated in Nigeria (Arise et al., 2016, Oyeyinka et al., 2016).

Lately, increased in consciousness in plant food-based products have been reported, due to growing awareness of nutritional benefits by health-conscious consumers (Darra et al., 2005). Recent development in human nutrition calls for cheap and abundant plant protein foods, in which Bambara groundnut is one. Animal food products are expensive and out of reach of majority of our masses and are high in cholesterol which has been implicated in coronary heart diseases (CHD) etc.

Over the years, legumes have been successfully converted into low-cost edible product with high nutritional values. In these regards, scholars have focused on products such as yoghurt, cheese analogue, ripened cheese, butter milk, and milk etc (Chan et al.,1992) and Soya beans are common ingredients used for making seed spread and therefore, need to explore others seeds such as Bambara groundnut.

Spreads are food literally spread, with a knife unto food products such as bread and crackers. Normally, spread is added to food in order to enhance their flavour or and texture of the food, which may consider "bland" without it.

Spread food are prepared in a paste, syrup or liquid from ground food such as fruits and nuts (Ottehenghi, 2006) Spread are different from dips, which are generally not applied to spread onto food but have food dipped onto into them instead(Catherine Saxelby 2012)

Common spreads include dairy spread such as cheese, cream and butter. The term butter is broadly applied to many spreads such as jams, jellies and hummus. Yeast spreads such as vegemite and marmite and meat-based spread such as pate. Peanut (Arachis hypogea) spread is commonly found in Nigeria. Peanut spread contains a high level of fat $(50 \mathrm{~g} / 100 \mathrm{~g}), 75 \%$ calories, protein $(25 \mathrm{~g} / 100 \mathrm{~g})$ but low in some essential amino acid such as methionine etc. Peanut is among the plant product that has been implicated in allergic reaction. The Food Allergy Research and Education (FARE)cautions people with nut allergy to avoid peanuts.

Unlike pea nuts, Bambara groundnut is high in protein quotient, highest concentration of soluble fibres and low in fats among other beans. These has enhanced its quality as a nutritious food which reduces the incidence of 
heart diseases and certain types of cancer (Tharanathan and Mahadevamna 2003; Arise et al., 2016.) Roasted Bambara groundnut smells and taste like roasted peanuts (Yusuf et al., 2008) but has not be implicated in allergies like peanut (FARE) and dairy (Philip 2014). Dairies are particularly high in cholesterol, which is one of the causes of coronary heart disease or atherosclerotic, heart disease. Rare fewer than 100 thousand cases per year has been reported in Nigeria (source College of Medicine University of Ibadan and others). However, coronary heart disease can be prevented through healthy diet, regular exercise and maintaining a heathy weight and not smoking. (source College of Medicine University of Ibadan and others)

Bambara groundnut based spread may provide additional nutritional benefits that are beyond simple nutrition for consumers due to their hypolipidemic, hypoglycaemic, anti cholestromic and anti-atherogenic properties and reduced food allergenicity ( Mesial et al.,; Lopez-Lazoro et al.,2002; Habeeb et al., 2012; Yusuf et al., 2017).

The use of Bambara groundnut in pastes, biscuits, bread and supplementation in cereal based have been reported. Low fat food spread from Bambara groundnut have not been reported. Therefore, there is dearth of information. This study explores the use of Bambara groundnut in production of low-fat spread.

\subsection{MATERIALS AND METHODS}

\subsection{Materials.}

The Bambara groundnut, (virginal subterranean) seeds were obtained from local farmers In Odu Ogbeyag, Dekina Local Government area of Kogi East, Kogi State, North-Central Nigeria. The salt and ascorbic acid were obtained from Hallmark supermarket, Sapele Road, Benin City, Edo State.

2.2 Method:The Bambara groundnut seed (500g) were roasted in an oven at $120^{\circ} \mathrm{C}$ for 1 hour. The roasted Bambara groundnut was cooled and blanched at $100^{\circ} \mathrm{C}$ for 8 minutes, dehulled and dried back to moisture contents of $12 \%$ at temperature of $60^{\circ} \mathrm{C}$ for 1 Hour in an oven (Jenway model). Milled into powder in stainless steel blender (Waring laboratory model HGBTWG4 USA) and homogenized with a laboratory Silverson homogenizer, while additives, salt, dextrose, ascorbic acid, yeast, gelatine and hydrogenated fat were all added, at varying levels of $6.5 \mathrm{~g}, 22 \mathrm{~g}, 2 \mathrm{~g}, 1 \mathrm{~g}, 44 \mathrm{~g}$ and $20 \mathrm{~g}$ respectively.

2.3 Proximate Analysis: The official methods of the American Association of Cereal Chemist (AACC, 1990) was used to determine moisture, crude protein, lipid, ash and crude fiber contents and carbohydrate by difference of the low -fat food spread.

2.4 Anti- nutritional factors Analysis: The method of Reddy et al., was used for phytate, Oxalate and Tannins and Trypsin inhibitor was done using spectrophometric method as described by (Arntfield et al.,)

2.5Amino Acids Analyses

The amino acid profile of the samples was analyzed by the water's API Quatro micro method with slights modification which consists of a column C18, 17um $2.1 \times 100 \mathrm{~mm}$ and a binary solvent manager.

2.6 Statistical Analysis: All analysis was done in triplicate and result were expressed as mean \pm SD analysis of variance (ANOVA) and the Pearson correlation coefficient were carried out using SPSS 17.0. A significant difference of $p \leq 0.05$ and 0.01 for Pearson correlation. The difference in mean were compared using Duncan's new multiple range test. 


\section{RESULTS}

Proximate Composition

\begin{tabular}{|c|c|c|c|c|c|c|}
\hline & Protein & Ash & Lipids & Moisture & Fiber & СHO \\
\hline $\mathrm{XY} 1$ & $22.19^{f} \pm 0.33$ & $3.0^{c} \pm 0.01$ & $7.01^{\mathrm{f}} \pm 0.01$ & $7.03^{d} \pm 0.03$ & $3.04^{c} \pm 0.04$ & $56.71^{\mathrm{a}} \pm 0.02$ \\
\hline $\mathrm{XY} 2$ & $23.04^{\mathrm{e}} \pm 0.02$ & $3.32^{\mathrm{a}} \pm 0.06$ & $9.41^{\mathrm{e}} \pm 0.04$ & $9.29 \mathrm{dc} \pm 0.03$ & $3.89^{b} \pm 0.29$ & $50.71^{b} \pm 0.01$ \\
\hline $\mathrm{XY} 3$ & $23.76^{d} \pm 0.08$ & $3.25^{b} \pm 0.08$ & $11.04^{\mathrm{d}} \pm 0.04$ & $12.04^{c} \pm 0.07$ & $3.56^{\mathrm{c}} \pm 0.00$ & $46.50^{c} \pm 0.50$ \\
\hline XY4 & $24.06^{c} \pm 0.02$ & $2.28^{\mathrm{f}} \pm 0.07$ & $13.00^{c} \pm 0.00$ & $11.72^{\mathrm{c}} \pm 5.82$ & $4.23 \mathrm{a} \pm 0.25$ & $41.22^{\mathrm{d}} \pm 0.40$ \\
\hline XY5 & $24.65^{b} \pm 0.05$ & $2.40^{\mathrm{e}} \pm 0.02$ & $17.17^{b} \pm 0.08$ & $17.07^{b} \pm 1.71$ & $3.26^{d} \pm 0.02$ & $34.26^{\mathrm{e}} \pm 0.80$ \\
\hline XY6 & $18.77 \mathrm{~g} \pm 0.10$ & $2.58^{d} \pm 0.03$ & $32.09^{\mathrm{a}} \pm 0.11$ & $16.83^{b} \pm 1.02$ & $2.40^{f} \pm 0.05$ & $21.71 \mathrm{~g} \pm 0.31$ \\
\hline
\end{tabular}

\begin{tabular}{lllllll}
$\mathrm{XY7}$ & $25.34^{\mathrm{a}} \pm 0.25$ & $2.20^{\mathrm{f}} \pm 0.01$ & $5.60 \mathrm{~g} \pm 0.10$ & $37.64^{\mathrm{a}} \pm 0.13$ & $2.03^{\mathrm{g}} \pm 0.46$ & $27.08^{\mathrm{f}} \pm 0.21$ \\
\hline
\end{tabular} Where: XYI: 1:9 Peanut/BGN; XY2: 2:8 Peanut/BGN; XY3: 3:7 Peanut/BGN; XY4: 4:6 Peanut/BGN; XY5:5:5 Peanut/BGN; XY6: 100\% BGN and XY7 100\% Peanut

Amino Acid Composition of Low-fat Food Spread

\begin{tabular}{|c|c|c|c|c|c|c|c|c|}
\hline & $\mathrm{XY} 1$ & $\mathrm{XY} 2$ & $\mathrm{XY} 3$ & $\mathrm{XY} 4$ & XY5 & XY6 & $\mathrm{XY} 7$ & $\mathrm{FAO} / \mathrm{WNO}$ \\
\hline Lysine & $6.45^{e} \pm .02$ & $6.83^{d} \pm .14$ & $6.94^{d} \pm .36$ & $7.36^{c} \pm 02$ & $7.78^{b} \pm 08$ & $6.15^{i} \pm 02$ & $9.20^{a} \pm 09$ & 4.2 \\
\hline Histidine & $2.76 \mathrm{~g} \pm .01$ & $2.97^{f} \pm .01$ & $3.11^{\mathrm{e}} \pm .10$ & $3.36^{c} \pm .01$ & $3.56^{c} \pm 01$ & $4.03^{b} \pm 06$ & $4.73^{a} \pm 01$ & \\
\hline Arginine & $6.75^{f} \pm .01$ & $7.24^{e} \pm 01$ & $7.73^{\mathrm{d}} \pm .03$ & $7.86^{\mathrm{c}} \pm .01$ & $8.74^{b} \pm 02$ & $6.58 \mathrm{~g} \pm 01$ & $10,18^{a}=03$ & 2.0 \\
\hline Aspartic acid & $10.26^{\mathrm{f}} \pm .02$ & $11.10^{c} \pm .03$ & $12.01^{d} \pm .02$ & $12.31^{\mathrm{c}} \pm 01$ & $13.81^{\mathrm{b}} \pm 01$ & $6.88^{8} \pm .01$ & $15.19^{\mathrm{a}} \pm 02$ & \\
\hline Threonine & $3.38^{f} \pm 01$ & $3.54^{e} \pm .00$ & $3.70^{\mathrm{d}} \pm .01$ & $3.87^{\mathrm{c}} \pm 01$ & $4.02^{\mathrm{b}} \pm 03$ & $3.20^{\mathrm{g}} \pm .01$ & $5.22^{\mathrm{a}} \pm 03$ & 2.6 \\
\hline Serene & $3.80^{\mathrm{f}} \pm 01$ & $4.08^{c} \pm .01$ & $4.35^{\mathrm{d}} \pm 01$ & $46.0^{c} \pm 01$ & $4.80^{b} \pm 02$ & $3.20^{\mathrm{g}} \pm 01$ & $6.98^{\mathrm{a}} \pm 01$ & \\
\hline Glutamic acid & $3.94^{e} \pm .04$ & $15.21^{d} \pm .02$ & $16.55^{c} \pm 01$ & $17.86^{c} \pm .02$ & $19.23^{b} \pm 03$ & $12.58^{\mathrm{g}} \pm 03$ & $20.40^{\mathrm{a}} \pm 00$ & \\
\hline Proline & $3.33^{\mathrm{f}} \pm .03$ & $3.61^{\mathrm{e}} \pm 01$ & $3.90^{\mathrm{d}} \pm 00$ & $41.6^{c} \pm 01$ & $4.44^{\mathfrak{c}} \pm 02$ & $4.86^{b} \pm .02$ & $4.96^{a} \pm 02$ & \\
\hline Glycine & $4.36^{\mathrm{f}} \pm .01$ & $4.46^{f} \pm 01$ & $4.94^{c} \pm 01$ & $5.35^{\mathrm{c}} \pm .17$ & $5.51^{a} \pm 01$ & $4.63^{e} \pm 01$ & $6.64^{a} \pm 01$ & \\
\hline Alanine & $4.63^{\mathrm{f}} \pm .03$ & $4.93^{\mathrm{f}} \pm .03$ & $5.32^{c} \pm .16$ & $5.73^{\mathrm{a}} \pm .0$ & $5.78^{\mathrm{a}} \pm 03$ & $4.05^{\mathrm{f}} \pm 01$ & $6.07^{a} \pm 00$ & \\
\hline Cystine & $1,12 \pm 00$ & $1.28^{\mathrm{d}} \pm .03$ & $1.37^{\mathrm{c}} \pm 01$ & $1.5^{\mathrm{a}} \pm 02$ & $1.63^{c} \pm 03$ & $1.20^{f} \pm 01$ & $1.09^{\mathrm{a}} \pm 00$ & \\
\hline Valine & $4.01^{\mathrm{dd}} \pm 01$ & $4.04^{c} \pm .01$ & $4.05^{c} \pm 00$ & $4.15^{b} \pm 00$ & $3.95^{\mathrm{d}} \pm 00$ & $4.27^{a} \pm 11$ & $3.10^{f} \pm 05$ & 4.2 \\
\hline Methionyl & $1.35^{\mathrm{e}} \pm .01$ & $1.40^{\mathrm{d}} \pm 00$ & $1.45^{\mathrm{b}} \pm 00$ & $1.50^{\mathrm{a}} \pm 00$ & $1.56^{\mathrm{a}} \pm 00$ & $1.36^{\mathrm{d}} \pm 00$ & $1.52^{a} \pm 00$ & 2.2 \\
\hline Isoleucine & $3.80^{e} \pm 01$ & $4.06^{\mathrm{d}} \pm .00$ & $4.39^{c} \pm 00$ & $4.67^{b} \pm 01$ & $4.98^{\mathrm{a}} \pm 00$ & $3.45^{\mathrm{f}} \pm 00$ & $5.71^{\mathrm{d}} \pm 01$ & 4.2 \\
\hline Leucine & $7.00^{\mathrm{b}} \pm 00$ & $6.76^{\mathrm{d}} \pm .02$ & $6.25^{\mathrm{d}} \pm 00$ & $6.15^{f} \pm 00$ & $6.95^{c} \pm 01$ & $7.27^{\mathrm{a}} \pm 03$ & $6.70^{c} \pm 02$ & 4.2 \\
\hline Tyrosine & $3.84^{c} \pm 00$ & $3.16^{\mathrm{e}} \pm .00$ & $3.46^{d} \pm 00$ & $3.79^{c} \pm 00$ & $4.25^{b} \pm 00$ & $4.87^{a} \pm 23$ & $3.77^{\mathrm{c}} \pm 24$ & 1.4 \\
\hline Phenylamine & $3.92^{\mathrm{c}} \pm 0.2$ & $3.83^{e} \pm .02$ & $3.80^{\mathrm{d}} \pm 00$ & $3.76- \pm .02$ & $4.86^{b} \pm 02$ & $4.86^{\mathrm{a}} \pm 02$ & $3.95^{c} \pm 00$ & 2.8 \\
\hline
\end{tabular}

Where: XYI: 1:9 Peanut/BGN; XY2: 2:8 Peanut/BGN; XY3: 3:7 Peanut/BGN; XY4: 4:6 Peanut/BGN; XY5:5:5 Peanut/BGN; XY6: 100\% BGN and XY7 100\% Peanut 


\begin{tabular}{|c|c|c|c|c|}
\hline - & OXALATE (mg/g) & TANINS (mg/g) & $\mathrm{TIU}(\mathrm{TIU} / \mathrm{mL})$ & PHYTATE $(\mathrm{mg} / \mathrm{g})$ \\
\hline \multicolumn{5}{|l|}{ - } \\
\hline $\mathrm{XY} 1$ & $1.78^{e} \pm 0.03$ & $8.69^{f} \pm 0.27$ & $1.75^{\mathrm{f}} \pm 0.35$ & $40.25^{b} \pm 0.84$ \\
\hline $\mathrm{XY} 2$ & $1.25^{\mathrm{f}} \pm 0.01$ & $12.94^{\mathrm{e}} \pm 0.39$ & $3.52^{e} \pm 0.59$ & $35.53^{\mathrm{c}} \pm 0.26$ \\
\hline $\mathrm{Xy} 3$ & $3.50^{\mathrm{d}} \pm 0.13$ & $17.41^{d} \pm 0.51$ & $5.23^{\mathrm{d}} \pm 0.05$ & $31.76^{d} \pm .27$ \\
\hline $\mathrm{XY} 4$ & $4.39^{c} \pm 0.17$ & $22.34^{c} \pm 0.25$ & $6.96^{c} \pm 0.71$ & $27.08^{e} \pm 0$ \\
\hline $\mathrm{XY} 5$ & $5.33^{b} \pm 0.08$ & $26.72^{b} \pm 0.18$ & $0.51^{b} \pm 0.03$ & $21.06^{\mathrm{f}} \pm 0.71$ \\
\hline XY6 & $0.95^{\mathrm{g}} \pm 0.05$ & $5.20^{\mathrm{g}} \pm 0.18$ & $0.51^{\mathrm{g}} \pm 0.03$ & $45.36^{a} \pm 0.36$ \\
\hline $\mathrm{XY7}$ & $9.04^{a} \pm 0.16$ & $39.81^{\mathrm{a}} \pm 1.00$ & $17.24^{\mathrm{a}} \pm 0.24$ & $0.00^{\mathrm{g}} \pm 0.00$ \\
\hline
\end{tabular}

Where: XYI: 1:9 Peanut/BGN; XY2: 2:8 Peanut/BGN; XY3: 3:7 Peanut/BGN; XY4: 4:6 Peanut/BGN; XY5:5:5 Peanut/BGN; XY6: 100\% BGN and XY7 100\% Peanut

\section{Discussion}

Proximate Composition of Low-fat Spread.

In general, protein content of spread formulated were' substantially higher compared to their flour counterparts, data not shown (table 1). The protein contents which ranged from $(18.77 \pm 0.10$ to $25.39 \pm 0.25)$ were significantly different $(P \leq 0.05)$. Sample XY7 had the highest protein content $(25.34 \pm 0.25)$. Dehulling of BGN has been reported to increase the protein content, the inner layers of the legume grain are comprise of cotyledon tissues which contains a large grain protein (Abiodun and Adepejun 2011) The increase in protein with the increase in the levels of substitution of peanut, agrees with the observations that peanut are good sources of protein. (Ibironke et al., 2012). The protein content of the XY7 was higher $(25.34 \pm 0.25)$ than that of XY6 $(18.77 \pm 0.10)$ and this indicates that peanut contain more protein than Bambara groundnut. Bambara groundnut is high in protein quotient, and low in fat. The high protein content of low-fat food spread will be of great importance in reducing protein- energy malnutrition, (Asma and Babiker, 2000). The Ash contents of the low-fat food spread significantly $\mathrm{P} \leq 0.05$ decreases with the increase in the percentage of peanut substitutions. Ash $(2.28 \pm 0.07-2.20 \pm 0.01)$ the decrease in ash contents observed in the sample substituted with peanut at different grade levels may be attributed to low mineral contents of peanut. The ash content of a food material could be used as an index for estimating the mineral constituents of food material (Ishiwu and Onyesi, 2004). The lipid content of the low- fat food spread samples was also significantly different $(5.60 \pm 0.10-32.09 \pm 0.11)$ XY6 with the lowest lipid content $(5.60 \pm 0.10)$ and XY7 with the highest lipid content $(32.09 \pm 0.11)$. This was expected with low fat content of BGN and higher fat contents for peanuts. Furthermore, the homogenization step employed in this study might have also influenced the fat content of the food spread, as was observed in yoghurt samples (Tammie et al., 2005). The reduction in fat content may be beneficial as it contributes to maintaining the quality of the spread, as the chances of rancidity are greatly reduced (Sunny-Roberts et al., 2004) The increase in the lipid content of the spread substituted with peanuts could attribute to the high lipids content of peanuts $\square$ (Oduro et al., 2007). However, lipids content of sample XY6 would enhance its quality as a nutritious food which reduces the incidence of heart diseases and certain types of cancer (Tharanathan and Mahadevamna 2003; Arise et al., 2016.) The moisture contents of the low fat food spread varied significantly $(\mathrm{P}<0.05)$, except sample $\mathrm{XY} 6$ and $\mathrm{XY} 5$ which were not significantly $(\mathrm{P}>0.05)$ different, and also sample $\mathrm{XY} 3$ and sample $\mathrm{XY} 4$ were also not significantly $(\mathrm{P}>0.05)$ different and means scores were very close, sample $\mathrm{XY} 7$ which is the control sample has the highest moisture than others. The moisture contents of all the formulated 
low-fat food spread reported in this study were within the recommended moisture contents of wet food (Bolarinwa et al., 2016). The crude fiber of the low-fat food spread (2.03-4.23) were significantly different $(\mathrm{P}<0.05)$, except for control sample $100 \%$ peanut which had fairs crude fiber content. The crude fiber contents of the low-fat food spread increased with increased substitution of peanut, this agrees with the report that peanut is rich in is of dietary fibers (Chan et al.,2004; Umar et al., 2013; Fashakin and Ige, 2014) and high concentration of soluble fiber has been reported for BGN (Tharanathan and Mahadevamna 2003). Fiber plays a significant role in the digestion and absorption of food in the human body. The carbohydrate contents $(21.71 \pm 0.31-56.71$ $\pm 0.02)$ of low-fat food spread samples were significantly lower $(\mathrm{P}<0.05)$. Expectedly, the decrease in the carbohydrate of the formulated sample could be attributed to high proportion of peanut used which is richer in protein. The carbohydrate contents of all the formulated low-fat food spread samples were lower than the carbohydrate content (69.2 to $74.5 \%)$ of food formulated from malted millet, plantain and soya bean reported by Adepeju et al.,2011 Barinwa et al., (2016). similarly observed same trends.

\section{AMINO ACIDS COMPOSITION OF LOW-FAT FOOD SPREAD.}

The amino acids of BGN were comparable to the WHO/FAO/UN reference although limiting in the Sulphur containing amino acid.

Table 2 depicts amino acids profiles of spread produced from BGN and supplemented with peanut. Samples $\mathrm{XY1}$, XY2, XY3, XY4, XY5, XY 6 and XY7 which serve as control respectively. Glutamic and aspartic acids which may include glutamic and asparagine respectively were most abundant amino acids in the spread and are also, most abundant amino acids in legumes. Okafor, et al., (2014) reported significant increase $(\mathrm{P} \leq 0.05)$ in protein content of roasted BGN flours. Similarly, significant increase in amino acids composition of the spread produced (table 2) was also observed in our study. This was in line with other authors reports, that dehulling of BGN increases the protein content. The inner layers of the legume grain are comprised of cotyledon tissues which contains a large grain protein (Abiodun and Adepejun 2011). Other scholars, similarly, reported that dehulling and roasting significantly $(\mathrm{P} \leq 0.05)$ increase protein contents due to loss of moisture (FAO, 1982, Adeyeye et al., 2006, Oyeyinka et al., 2016) and reduced anti-nutritional factors and antioxidant activities relatively (Oyeyinka et al., 2016. However, total Sulphur amino acid ranged $(2.40-3.19 \mathrm{~g} / 100)$ lower than $(5.8 \mathrm{~g} / 100 \mathrm{~g})$. FAO/WHO, amino acids score recommended for adults. Aromatic amino acids which include phenylamine and tyrosine ranged $(6.99-9.73 \mathrm{~g} / 100)$ higher than suggested minimum $(6.8 \mathrm{~g} / 100 \mathrm{~g})$ for infants, children and adults (FAO/WHO/UN 1985). Acidic amino acid was found more abundant compared to basic amino acids $(20-36.59 \mathrm{~g} / 100 \mathrm{~g}$ and $6.79-9.75 \mathrm{~g}$ respectively. Suggested that protein in the food spread was probably more acid in nature. Adeyeye et al., 2010, observed a similar trend in BGN flour. Total essential amino acids ranged (6.99 - 9.73) 41.72\% in the spread, considered well above $39 \%$ adequate in food for infants, $26 \%$ children and $11 \%$ for adults. Essential amino acids are those used for the synthesis of body protein that can only be obtained from diet (Isang et al., 2009; Yusuf et al., 2016). The spread samples would supply virtually all the required essential amino acids. Bambara groundnut is a good source of amino acids and will be useful for producing food spread that will enhance nutrients intake. The variation observed in the amino acid composition of the spread was as a result of the various matrices and substitution of peanuts.

Anti-Nutritional Factors of Low-fat food spread

The result of the anti-nutritional factors composition of formulated low-fat food spread presented on table 3 . The oxalate contents varied significantly $(\mathrm{P} \leq 0.05)$ from each other with sample $X Y 7$, the control samples having the highest oxalate content. The increase in the oxalate contents observed in this study is attributed to the increase in substitution of peanut spread. The oxalate content ranges from $1.78 \pm 0.03$ to $9.04 \pm 0.16$ for control samples respectively. The oxalate contents increased with the increase in the percentage of peanut but were within the permissible limit of $5 \mathrm{mg}$.

Tannins contents of the formulations varied $5.20 \pm 0.18$ to $39.81 \pm 1.00$ and were significantly $(P \leq 0.05)$ different from each other though the level was highest in XY6 sample (100\% Bambara groundnut). The increase observed was as a result of increased percentage of peanut spread substitutions, indicates that, tannins were higher in Bambara groundnut compared to peanut. The level of tannins was within the permissible limit except sample XY5 and sample XY7 that were beyond the permissible limit due to peanut spread substituted. However, Sample XY6 was within the permissible limit, the test sample.

Trypsin inhibitor varies from $0.51 \pm 0.03$ to $17.24 \pm 0.24$, with the sample XY6 having the least trypsin inhibitor units (TIU). There was significant difference $(\mathrm{P} \leq 0.05)$ between the samples respectively. Trypsin inhibitor increased with increase percentage of peanut in the formulation except sample XY6 that had very low concentrations. This showed that trypsin in this formulation were above the permissible level except sample XY6 which was within the permissible limit. Trypsin inhibitors, according to Venter and Van Eyssen (2001) are 
compounds that interfere with protein digestion, they cause pancreatic enlargement and enhance chemically induced pancreatic tumours. However, the trypsin inhibitors are heat-labile in nature and this suggests that they can be inactivated by cooking (Prathibha et al., 1995). Reports, indicate that in well cooked foods, the trypsin inhibitors may not interfere with digestion (Adane et al. 2013)

The phytate ranged $0.00 \pm 000-40.25 \pm 0.84$ with sample XY7 having the least phytate level or zero level. Indicated significant $(\mathrm{P}<0.05)$ difference among the samples. The phytate levels decreased with the increased amount of the peanut substitutions except sample XY6, without peanut. This implies that Bambara contain level of phytate inherent. The phytate level of all the samples were below the permissible level of (250mg). Antinutritional factors such as phytate have been implicated in the chelating of divalent mineral such as calcium, iron and magnesium (Mune et al. 2011). This results in reduced bioavailability of these nutrients in the body. According to Sharma, Agarwal and Verma (2011) soaking of legume in water for $24 \mathrm{hrs}$. at room temperature and at $55{ }^{\circ} \mathrm{C}$ decreased phytate content by $50 \%$ and $90 \%$ respectively.

Processing such as boiling/blanching, dehulling and roasting has been observed to reduced anti-nutritional factors and enhancement in quality and safety of low fat food anti-nutrients are more susceptible to moist heat than dry heat, therefore the significant reduction of anti-nutrient during processing implies that, the nutritional components of Bambara groundnut and peanut will be more bioavailable. This research reveals that Bambara groundnut has a high potential in correcting protein energy malnutrition in Nigeria since it is highly rich in carbohydrate and protein. The amino acids of Bambara groundnut were comparable to the WHO/FAO/UN reference although limiting in the Sulphur-containing amino acid. The lipid content of XY6 was considered lowest in all samples of low-fat food spread produced, would enhance its quality as a nutritious food which could reduce the incidence of heart diseases and certain types of cancer (Tharanathan and Mahadevamna 2000).

The amino acids of $\mathrm{BGN}$ were comparable to the WHO/FAO/UN reference although limiting in the Sulphur-containing amino acid.

\section{REFENCES}

Abiodun, A; Adepeju A. (2011). Effect of processing on chemical, pasting and anti-nutritional composition of Bambara nuts (Vigna subterranean l. verd c)

Adegunwa M; Adebowale A B; Kalejaiye K. (2014). Effects of treatments on anti-nutritional factors and functional properties of Bambara groundnut (Voandzela subterranean) flour. Journal of food processing and preservation 389 (4) : 1875-1881.

Adeyeye E.I 2010. Effect of cooking and roasting on the amino acid composition of raw groundnut (Arachis hypogea) seeds. Acta Sci. POI. Technol Aliment 19 (2) $201-216$.

Arise, A. K., Amonsou, E. O. and Ijabadeniyi, O. A. 2015. Influence of extraction methods on functional properties of protein concentrates prepared from South African Bambara groundnut la International Journal of Food Science and Technology, 50 (5): 1095-1101.

Borget, M. (1992) Food Legumes. In: The Tropical Agriculture, CTA Macmillan.

Bamshaiye, O Adegbola; Bamshaiye E (2011) Bambara groundnut. An underutilized nut in Africa. Advances in Agriculture Biotechnology 1: 60-72.20

Chan, C.F; Chen C.H; Lee, M.H (2004) Comparison of Characteristic, Functional Properties and In vitro Polysemic Effects of Various Carrot Insoluble Fibre-rich Fractions. Lebensmittel- Wissen Shaft and Technologies, 37: 155-160.

Diarra, K., Nong, Z. G. and Jie, C. 2005. Peanut milk and peanut milk-based products production: A review. Critical reviews in Food Science and Nutrition, 45 (5): 405-423.

Dooku, E V (2006). Growth Habit and production of Bambara groundnut (Voandzeia subterranean) Ghana

Flight, I. and Clifton, P. 2006. Cereal grains and legumes in the prevention of coronary heart disease and stroke: a review of the literature. European journal of clinical nutrition, 60 (10): 1145-1159.

Isang, J. and Zhang, G. 2009. Production and Evaluation of some Physicochemical parameters of peanut mill yoghurt. LWT Food Science and Technology, 42 (6): 1132 - 1138

Lopez-Lazaro, M. and Akiyama, M. (2002). Flavonoids as anticancer agents: structure-activity Relationship study. Current Medical and Chemistry of Anti-Cancer Agents. 2, 691-714.

Mangels Reed (20010) Guide to Nuts and Nut Butter, Vegetarian Journal 21, 20-23.

Mubarak, A. 2005. Nutritional composition and antinutritional factors of mung bean seeds (Phaseolus aureus) as affected by some home traditional processes. Food Chemistry 89 (4):489-495.

Mune, M., Minka, S. R., Mbome, I. L. and Etoa, F. 2011b. Nutritional potential of Bambara bean protein concentrate. Pakistan Journal of Nutrition, 10 (2): 112-19.

Nielsen, P. M., Petersen, D. and Dambmann, C. (2001). Improved method for determining food protein degree of hydrolysis. Journal of Food Science, 66, 642-646

Okafor JNC; Ani J.C, Okafor G.I 2014. Effect of processing methods on qualities of BBAN Voandzela subterranean (L/Thouars) Flour and Their Acceptability in Extruded Shacks American journal of 
Technology 9 (7) $350-359$.

Omijie, A B, Yusuf A O, 2018. 2018. Proximate Composition and Consumer's Acceptability of low-fat from Bambara groundnut Project work, Department of Food Technology, Auchi, Polytechnic, Auchi, Nigeria.

Oyeyinka, S. A., Singh, S., Adebola, P. O., Gerrano, A. S. and Amonsou, E. 2015.

Physicochemical properties of starches with variable amylose contents extracted from Bambara groundnut genotypes. Carbohydrate Polymers, 133: 171-78.

Saxelby Catherine (2012) Complete Food and Nutrition Companion: https:/nia gov.au.nia catun 60048.tveson

Stevenson to, D. G., ELLER, F. J., Wang, L.; Jane, J.; Wang, T.; and Ingett, G.E. (2007). Oil and Tocopherol Content and Composition of Pumpkin Seed in 12 Cultivars. Journal of Agricultural food Chemistry 55: $4005-B$.

Tharanathan, R. and Mahadevamna, S. 2003. Grain legumes-a boon to human nutrition. Trends in Food Science \& Technology, 14 (12): 507-518

Tharanathan, R. and Mahadevamna, S. 2003. Grain legumes-a boon to human nutrition. Trends in Food Science \& Technology, 14 (12): 507-518.

Yotan, Ottolenghi (200) The New vegetarian. The New Vegetarian. The Guardian weekly columns, England.

\section{ACKNOWLEDGEMENT}

The Scholars are indeed grateful to TETFUND for the opportunity afforded them to contribute to knowledge and nation building in terms of food innovation. 